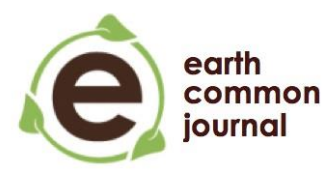

Earth Common Journal

Changing Climates: Social, Political, Economic

MacEwan University

Volume 6, Number 1, October 2016

\title{
Article
}

\section{Responding to Environmental Challenges in Alberta}

\author{
Peter Brown, MacEwan University, Canada*
}

\begin{abstract}
Climate change and the myriad of challenges that come with it are a reality the entire world must face. However, for Canadian province, Alberta, the stakes are especially high. Oil and gas mining made up 18.3\% of Alberta's GDP in 2015 and therefore plays a significant role in its economy. Alberta has also been subject to degrading air quality and natural disasters like the recent Fort McMurray Fire. Provincial and municipal governments have, however, taken many steps to addressing the array of environmental challenges Alberta faces including releasing its Climate Leadership Report to Environment Minister Shannon Phillips, which outlines concrete goals and objectives. This paper discusses some of targets as well as legislation that have come out of the Climate Leadership Report. Furthermore, this paper explores how individuals have influenced the climate change discussion and how they can continue to spread environmental messages.
\end{abstract}




\section{Introduction}

Climate change and the myriad of challenges that come with it is a reality the entire world must face. However, as shown in the pie graph (Economic Diversity: 2015), for Canadian province, Alberta, the stakes are especially high. Alberta is home to some of Canada's largest energy producers, and a large part of its GDP comes from oil and gas mining-18.3\% in 2015 ("Economic Results," 2015). The greenhouse gases from fossil fuels also have severe consequences for Alberta's air temperature and quality. Already, Alberta has begun to acknowledge and respond to climate change at both individual and municipal levels and for the sake of future generations' wellbeing, it is imperative that this continue. The following paper will examine the issue of climate change in Alberta as well as in its capital, Edmonton. Edmonton is Canada's fifth largest city with a population of 1,328,290 (Lamphier, 2015, para. 2). This paper will outline specific environmental challenges Alberta faces and what the province is doing to combat them.

Alberta has had its share of environmental woes in 2016, most notably the Fort McMurray fire that blazed for more than two months before being declared under control. The fire's legacy is stark, having covered more than 500,000 hectares at its height — an area bigger than Canada's Prince Edward Island ("The Fort McMurray Fire," 2016, para. 8). But even back in 2015, the Canadian Ambient Air Quality Standards report showed regions of Alberta approaching or, in Red Deer's case, exceeding the Federal government's acceptable amount of particulate matter (solid and liquid airborne particles) and ozone exposure ("Red Deer area," 2015, para. 1-4_). In light of these findings, Alberta Environment Minister Shannon Phillips warned that the province was on its way to having the worst air quality in Canada ("Red Deer area," 2015, para. 4). While particulate matter exists in earth's atmosphere naturally, man-made pollutants like from cars or power plants have increased its prevalence ("Red Deer area," 2015). However, it is not just the poor air-quality that plagues Edmonton.

Back in 2008, Edmonton's city council aimed to halve greenhouse gas emissions by 2020. Unfortunately, the city is far from this target with its emissions continuing to grow; in 2015, emissions of $\mathrm{CO}_{2}$ reached a five-year high of 353,870 t (Stolte, 2016, para. 2). That said, both city and provincial governments continue to evaluate and reassess what steps can be taken to combat climate change. The Alberta Climate Leadership Panel (ACLP) acknowledges in its 2016 report to the minister, that for Alberta to meet global climate change goals, the province must reduce "the use of coal and oil, and [increase] use

of natural gas and renewable energy" (p. 4). Furthermore, the Panel acknowledges Alberta is already "experiencing real impacts from the status quo" (p.4).

ECJ Volume 6, No. 1, 2016: Changing Climates - Social, Political, Economic 
Of course, simply acknowledging our hand in the emergence of these environmental challenges is not sufficient. Fortunately, the ACLP's report-one informed by engagement with the public, technical stakeholders, and members of Aboriginal communities — has translated into concrete government policy. On May 24, 2016, Alberta Environment and Parks Minister Shannon Phillips introduced Bill 20: the Climate Leadership Implementation Act (Olexiuk, Carson, Saric, Jatoi, \& Lemke, 2016, para. 1). The bill, which goes into effect on January 1, 2017, will place a carbon levy on fuel purchases, instate carbon prices of $\$ 20 / \mathrm{t}$ in 2017 and $\$ 30 / \mathrm{t}$ in 2018 , introduce consumer carbon-levy rebates, as well as other changes. The levy, in particular, is expected to raise $\$ 3$ billion, which the government will then use exclusively for environmentally-focused initiatives (Bennett, 2016, para. 2 \&11). Furthermore, because the levy will raise the price of gasoline by 4.49 cents a litre, individuals will likely adopt greener behaviour (para. 17). Looking forward to more long-term commitments, the Panel's report also stated a goal of phasing out coal power by 2030. In doing so, the Panel (2016) writes, there will be an "opportunity for the replacement of at least $50-75 \%$ of retired coal generation with renewable power" (p.6).

\section{Framing Climate Change Messages}

Government commitments and legislation such as those outlined above will be crucial in battling climate change, but they are not the only piece necessary to combat climate change. Individual action will also play a vital role in creating a greener, more sustainable Edmonton. For individuals to appropriately act, however, they must be informed about the environmental issues that we as a city, a province, and a world face. One way to accomplish this is to maintain an ongoing public dialogue. This is a delicate task. Research into psychological barriers indicates that many climate change messages are ineffective in encouraging individual action because they are framed too negatively or too broadly. Feinberg and Willer (2011) explore the effect of dire global-warming messages on individuals with varying levels of belief in a world that is "just, orderly and stable" (p. 1). Participants were randomly assigned to read one of two articles. While both articles provided information on climate change, they differed in focus-one article focused on the dire consequences of global warming, the other, on potential solutions. The researchers found that the dire message left participants more skeptical of global warming, while the positive message led to an overall decrease in skepticism (p. 35). Broad or ambiguous messages about climate change, however, can also encourage audience inaction (p. 36). 
Beyond framing messages in a positive light, communicators must also lead with what they know. All science is imperfect and contains many points of uncertainty. Unfortunately, climate scientists are often especially faulted for what they do not know. The Uncertainty Handbook argues that as a result, scientists' apologies often obscure important messages about climate change (Corner, Lewandowsky, Phillips \& Roberts, 2015 , p.4). In this same vein, communicators must switch the framing of their climate change messages from 'uncertainty' to 'risk.' Risk, they write, 'is the language of the insurance, health and national security sectors [and is, therefore] likely to be more effective than...uncertainties" (p. 8). A risk framework allows communicators to talk about close-to-home consequences like floods or droughts instead of more abstract ones. Steering the message into the concrete also lessens its potential controversy (p.8). The authors of Climate Crossroads, The Topos Partnership, Pike and Herr (2009), propose a 'common message platform' that seems to take findings like Feinberg and Willer (2011) to heart. The Climate Crossroads Executive Summary outlines a holistic set of points that communicators can make without overwhelming their audience with dire messages. Among their recommendations, is emphasizing that "humans are releasing too much carbon into the air" (The Topos Partnership et al., 2009, p.10). Facts like these, they argue, will strengthen a communicator's argument because they are well-accepted facts even among climate-change naysayers. Ideas like these act as springboards to bigger conversations about why too much carbon is bad for the environment and encourage action on individual and governmental levels (p. 10).

\section{Café Pracademique: Mobilizing Eco-citizens}

Recently, Café Pracademique, an initiative spearheaded by the Edmonton chapter of the Institute of Public Administration of Canada (IPAC) hosted a workshop event called Green is the New Black: Mobilizing Eco-Citizens. The event gathered practitioners, academics and citizens to discuss solutions to challenges Alberta is facing in the area of environment and sustainability. Café participants heard success stories from speakers whose work drew on social psychology and were then challenged to define and design sustainability at the individual, citizen level in a series of breakout sessions. In each breakout group, one person was responsible for facilitating, another for taking notes. The Café Pracademique committee extracted two participant suggestions for the creation of better environment and sustainability policy: 1) fostering a culture of sustainability that supports individual action and 2) empowering citizens to adapt promising eco-friendly behaviours to their specific local context (Café Pracademique, 2016). The Café participants also noted examples of environmentally focused technologies, services, and government legislation around the world including Canadian city Montreal's bike-sharing 
system Bixi, an opt-in contribution to power bills in Germany that promotes solar panel usage, Vancouver's municipal composting program, among others. After the 2016 Café Pracademique season ended in April, members of the committee, including Pracademic chair Jared Wesley, presented their findings at both the Canadian Political Science Association meeting in Calgary and the IPAC National Conference in Toronto (Jared Wesley, personal communication, 2016, August 25). The implications for the environment café are that many Edmontonians are well-informed about environmental initiatives nationally and internationally and can be a rich resource for city and provincial governments when they develop policies and legislation.

\section{Conclusion}

It is clear that a lot is at stake here in Alberta. We face climate change and the degradation of our air quality among countless other environmental challenges. Furthermore, in a province whose economy relies so heavily on energy production, environmental action has additional barriers. These issues, however, will not simply disappear on their own, which is why it is important that we be aware of the consequences of our actions. Perhaps even more importantly, we must recognize what steps we can take to get informed about environmental issues and then use effective frameworks to communicate about them to others. It is these conversations that will continue to inform government policies, legislation, and priorities. Working together as eco-citizens to foster change will lead to a healthier planet for our generation and future generations.

* Author: Peter Brown is a student in the Bachelor of Communications program at MacEwan University. Peter will soon graduate from MacEwan. This is his second year as an editor and his first year as a writer for Earth Common Journal. Peter looks for ways to be eco-friendly in everyday life and revels at a chance to spread his knowledge on the topic. He enjoys writing, editing, photography and design, and can be reached for project inquiries atpuwbrown@gmail.com

\section{References}

AlbertaCanada (2015). Economic Results. Retrieved from

http://www.albertacanada.com/business/overview/economic-results.aspx 
Café Pracademique (2016). Green is the new black: Mobilizing eco-citizens [video].

Retrieved from https://cafepracademique.com/es/Corner, A., Lewandowsky, S., Phillips, M. and Roberts, O. (2015) The Uncertainty Handbook. Bristol: University of Bristol.

Feinberg, M., Willer, R. (2011, Jan). Apocalypse Soon? Dire Messages Reduce Belief in Global Warming by Contradicting Just World Beliefs. Psychological Science. 22(1), 34-38. doi: 10.1177/0956797610391911

Lamphier, G. (2015, Feb 12). "Edmonton now Canada's 5th largest metro region.” Edmonton Journal. Retrieved from http://edmontonjournal.com/business/localbusiness/edmonton-area-tops-ottawa-gatineau-as-nations-5th-largest-metro-region

Leach, A., Adams, A., Cairns, S., Coady, L., \& Lambert, G. (2016). Climate Leadership Report to Minister. Retrieved from http:/ /www.alberta.ca/documents/climate/climate-leadership-report-tominister.pdf

Olexiuk, P., Carson, L., Saric, D., Jatoi, K., \& Lemke, K. (2016). Alberta’s carbon tax Bill 20: the Climate Leadership Implementation Act. Retrieved from https://www.osler.com/en/resources/regulations/2016/alberta-s-carbon-taxbill-20-the-em-climate-le

Red Deer area exceeds air-quality limits; environment minister concerned. [Video file]. (2015, Sept. 9). Retrieved from http://globalnews.ca/news/2211454/red-deer-area-exceedsair-quality-limits-environment-minister-concerned/

Stolte, E. (2016, June 14). "Checkup finds Edmonton falls far short of target on greenhouse gas emissions." Edmonton Journal. Retrieved from http:/ /edmontonjournal.com/news/local-news/checkup-finds-edmonton-fallsfar-short-of-target-on-greenhouse-gas-emissions

The Canadian Press Staff (2015, Sep. 9). "Red Deer area exceeds air-quality limits; environment minister concerned." Global News. Retrieved from http://globalnews.ca/news/2211454/red-deer-area-exceeds-air-quality-limitsenvironment-minister-concerned/

The Globe and Mail. (2016, June 10). “The Fort McMurray Fire: What's happening now, and what you've missed." The Globe and Mail. Retrieved from 
http://www.theglobeandmail.com/news/alberta/the-fort-mcmurray-disasterread-the-latest-weekend/article29930041/

The Topos Partnership, Pike, C., \& Herr, M (2009). Climate Crossroads: A Research-based Framing Guide. 